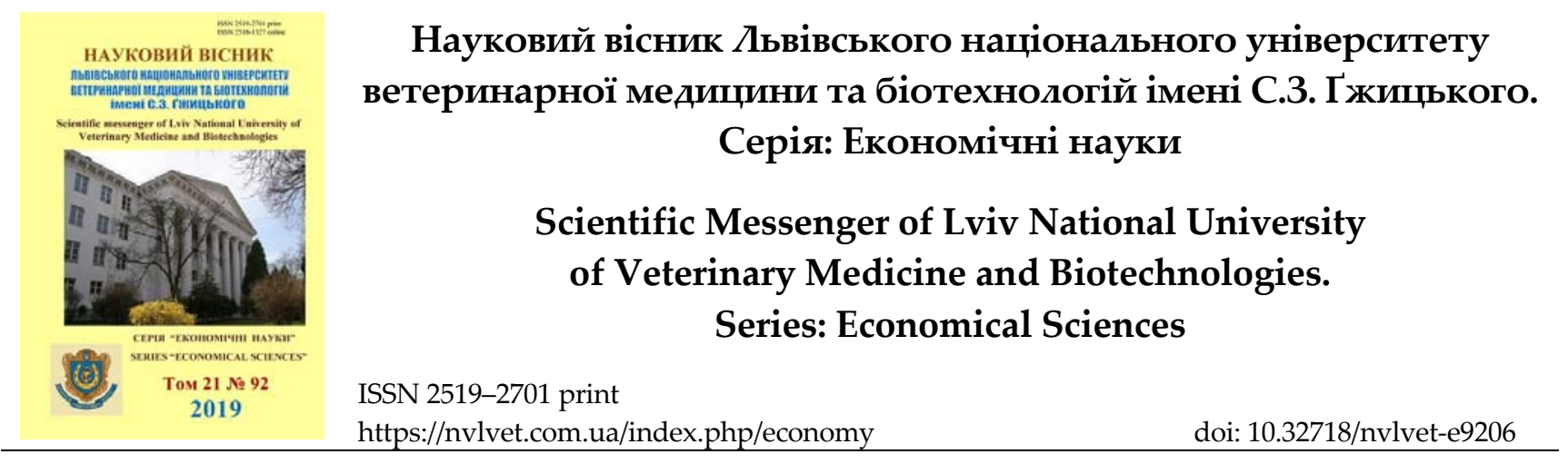

UDC 631.115.11:637.11

\title{
Economic framework of dairy family farms development
}

\author{
V.A. Chemerys, V.I. Dushka, V.L. Maksym, D.O. Solomonko \\ Stepan Gzhytskyi National University of Veterinary Medicine and Biotechnologies Lviv, Ukraine
}

Article info

Received 17.01.2019

Received in revised form 22.02 .2019

Accepted 25.02.2019

Stepan Gzhytskyi National University of Veterinary Medicine and Biotechnologies Lviv,

Pekarska Str., 50, Lviv, 79010, Ukraine.

Tel.: +38-032-239-26-56 E-mail:volodiamaxym88@gmail.com
Chemerys, V.A., Dushka, V.I., Maksym, V.L., \& Solomonko, D.O. (2019). Economic framework of dairy family farms development. Scientific Messenger of Lviv National University of Veterinary Medicine and Biotechnologies. Series: Economical Sciences, 21(92), 33-42. doi: 10.32718/nvlvete9206

One of main industry of livestock in Ukraine there is the dairy farming on the cost of gross value products, development of which status substantially influences on food security providing and AIC export potential forming. However much the about two third of industry gross value products made by households, which are characterized with the low level of efficiency and marketability. In the article the conducted researches are in relation to development dairy cattle breeding in Ukraine by creation of farms, including family type, on the base of households. Achievement of the put purpose, in our viewpoint, possible at forming of economic interest to work in dairy farming at the active rural population. As a result of research certainly basic economic criteria of farms development taking into account the maximum scales of production activity, cost of sales, and also necessary level of technological and economic efficiency, which will be instrumental in the successful functioning of such economic agent. The economic framework of dairy production is developed in the family farms of three types, which differ on the quantity of cows and sales prices for milk. Certainly, that the cost of the advanced capital which is needed for milk production organization in family farms will differ from 25 to 60 thousand euro taking into account state support indemnifications on the purchase of the fixed assets, scales of production and present material and technical resources of households, which creation is offered on the base of. Creation of farms with a herd not less than 20 cows at the farm gate wholesale milk price and also farms with a herd not less than 9 cows, in a that number the already existent households created on a base subject to condition organization sales of total mine-out products on prices which are close to the retail, with the purpose of average monthly sufficient sum of cash flow achievement which will be instrumental in forming economic and investment interest, among the capable of working habitants in rural areas to produce milk is offered. Recoupment of such farms depending on the scales of production, milk sale prices and level of state support, will make from 3 to 6 years. The important condition of rapid family farms recoupment is a state support level, cows productivity and milk prices. Also certainly basic indexes of economic efficiency and investment attractiveness of milk production in the offered three types of farms. Conducted economic analysis of main indexes of efficiency, on the basis of which the best possible option dairy family farm is justify. The scientifically substantiated that family dairy farms development on the base of households in rural areas will be instrumental in the increase of economic potential of the dairy farming in Ukraine.

Key words: dairy farming, family farm, rural areas, production, economic efficiency.

\section{Економічне обгрунтування розвитку сімейних ферм з виробництва молока}

\author{
В.А. Чемерис, В.І. Душка, В.Л. Максим, Д.О. Соломонко
}

Львівський національний університет ветеринарної медицини та біотехнологій імені С.3. Гжицького, м. Львів, Украӥна

Однією з основних галузей твариннищтва Украӥни за вартістю виробленої продукції є молочне скотарство, стан розвитку якого суттєво впливає на продовольчу безпеку та формування експортного потенціалу АПК. Однак близько двох третин виробленої продукиї галузі припадає на господарства населення, які характеризуються низьким рівнем ефективності та товарності 
виробництва. У статті проведені дослідження щуодо розвитку молочного скотарства України шляхом створення ферм, у тому числі сімейного типу на базі господарств населення. Досягнення поставленої мети, на наш погляд, можливе при формуванні в активного сільського населення економічного інтересу працювати у молочному бізнесі. За результатами дослідження визначено основні економічні критерії розвитку ферм, з врахуванням граничних масштабів виробничої діяльності, ціни реалізації, а також необхідного рівня технологічної та економічної ефективності, який сприятиме успішному функиіонуванні таких господарств. Розроблено економічне обтрунтування виробництва молока у сімейних фермах трьох типів, які відрізняються за чисельністю корів та рівнем иүіни продажу молока. Визначено, щуо вартість авансованого капіталу, який необхідний для організації виробництва молока у сімейних фермах, становитиме від 25 до 60 тис. євро з врахуванням державних компенсацій на купівлю основних засобів, масштабів виробництва та наявних матеріально-технічних ресурсів тих господарств населення, на базі яких пропонується створення ферм. Також визначено основні показники економічної ефективності та інвестиційної привабливості виробництва молока у запропонованих трьох типах ферм. Проведений економічних аналіз основних показників ефективності, на основі якого запропоновано та обтрунтовано найбільш оптимальний варіант сімейної ферми з виробництва молока.

Ключові слова: молочне скотарство, сімейна ферма, сільські території, виробництво, економічна ефективність.

\section{Вступ}

Молочне скотарство, за сприятливих ринкових умов, відноситься до перспективних високоприбуткових видів агробізнесу, який необхідно розвивати для забезпечення споживчих потреб населення у молоці та молокопродуктах, а також 3 метою формування експортного потенціалу агропродовольчого підкомплексу України. Однак, стан галузі молочного скотарства в Україні не відповідає їі економічному потенціалу. Значна частка молочної продукції виробляється господарствами населення, які відносяться до низькотоварних екстенсивних форм виробництва. Чисельність таких господарств, в силу відсутності економічних передумов та стимулів функціонування, щороку зменшується, а їх ніша заповнюється сільськогосподарськими підприємствами. Відповідно набуває актуальності проведення комплексних досліджень щодо розвитку ферм 3 виробництва молока, в тому числі сімейного типу на основі господарств населення, що сприятиме підвищенню економічного потенціалу молочного скотарства України.

Вивченню перспективних шляхів розвитку молочного скотарства України присвячені праці багатьох вчених економістів, серед яких: Ю. Лупенко, О. Маслак, М. Малік, Л. Іванова, Д. Семенда, В. Ніценко, М. Пархомець О. Шпикуляк та інші. В іноземній науковій літературі питання розвитку ферм з виробництва молока розкрито у працях J. Špička, L. Smutka, Z. Zakova Kroupova, M. Michaličková, Z. Krupová, P. Polák, L. Hetényi, E. Krupa, P. Mamardashvili, D. Schmid та багатьох інших. Проте не достатньо дослідженими залишаються питання, які стосуються розвитку молочного скотарства шляхом створення ферм, в тому числі сімейних на базі господарств населення, які виробляють та реалізують основну частку сировини на ринку.

У 2017 р. агросектор, в якому зайнята третина громадян України, забезпечив 40\% усієї валютної виручки держави. Частка агровиробників у структурі ВВП України становить лише $12 \%$, але цей показник має тенденцію до зростання. Скотарство належить до провідних галузей аграрного сектору України. В структурі доходів від реалізації продукції тваринництва частка від продажу молока становить 26\% (Maslak, 2017).

В Україні склалися одні з найкращих умов у світі для виробництва молока та молочних продуктів. Разом із тим проблему насиченості ними ринку не вда- лося повною мірою вирішити навіть у найсприятливіші для розвитку молочного господарства роки (Ivanova, 2017). Однак, як зазначає Ніценко В., галузь молочного скотарства в Україні характеризується низькими темпами розвитку. Щорічно знижується поголів'я корів, продуктивність тварин (особливо в особистих господарствах населення не відповідає вимогам досвіду розвинених країн), матеріальнотехнічне забезпечення, кількість спожитої продукції населенням країни, завантаження виробничих потужностей переробних підприємств (Nitsenko, 2013).

Спеціалізовані молочні ферми є важливим типом ведення сільського господарства, але їхня важливість змінюється в ЄС. Частка виробництва молока на спеціалізованих молочних фермах у загальному обсязі виробництва молока в СС коливається від 24\% (Чехія) до 99,9\% (деякі регіони Іспанії та Португалії). Решту молочної продукції припадає на змішані ферми (Špička \& Smutka, 2014).

У світовій практиці розвиток сільського господарства пов'язується 3 розвитком сільських територій. Практика розбудови аграрного сектора в переважній більшості країн світу дає підстави стверджувати, що базовим підприємницьким чинником його конкурентоспроможного, сталого розвитку виступають «малі» форми, зокрема сімейні ферми, які можна вважати аналогом вітчизняних особистих селянських господарств (Malik \& Shpykuliak, 2018).

Трансформації розвитку вітчизняного агрогосподарського комплексу спричинили формування ринкової системи господарського порядку, у якій особливе місце займають особисті селянські господарства, зокрема господарства населення. Протягом тривалого часу вони відіграють вагому роль у виробництві сільськогосподарської продукції та забезпеченні розвитку сільських територій України (Malik \& Shpykuliak, 2018). Діяльність господарств населення забезпечує збереження й розвиток сімейної форми господарювання, самозайнятість членів селянських сімей та одержання ними додаткового доходу, а також розвиток сільських територій (Malik \& Shpykuliak, 2018).

Метою дослідження є економічне обгрунтування оптимальних варіантів створення сімейних ферм 3 виробництва молока на базі господарств населення для формування основних резервів розвитку галузі. Для досягнення поставленої мети вирішувалися наступні завдання: дослідити необхідну матеріальнотехнічну та сировинну базу для створення ферм 3 виробництва молока; обгрунтувати основні економіч- 
ні критерії розвитку ферм $з$ виробництва молока на базі господарств населення; визначити основні техніко-економічні та інвестиційні параметри організації ферм з виробництва молока.

\section{Матеріал та методи досліджень}

В процесі проведеного дослідження використано загальнонаукові методи, зокрема монографічний при комплексному та всебічному вивчені основних економічних проблем розвитку сімейних фермерських господарств України; аналіз та синтез - для визначення основних чинників та складових розвитку молочного скотарства на основі фермерських господарств, у тому числі сімейного типу; розрахунковоконструктивний метод використовувався при визначені основних економічних параметрів розвитку трьох варіантів сімейних ферм галузі молочного скотарства 3 врахуванням критеріїв розширеного відтворення, самоокупності та економічного інтересу, на основі яких визначено найбільш оптимальний. Матеріалами досліджень стали публікації вітчизняних вчених економістів, а також власні спостереження.

\section{Результати та їх обговорення}

Молочне скотарство відноситься до важливої і невід'ємної складової сільського господарства, яка зумовлює соціально-економічний стан усіх категорій господарств України. Протягом тривалого часу галузь перебуває у кризовій ситуації і зазнала найбільш руйнівних деструктивних змін через відсутність достатньої офіційної підтримки. Молочне виробництво в цілому поки що не зорієнтоване на кінцевий результат, немає визначених напрямів концентрації ресурсів й використання інвестицій (Semenda et al., 2018).

Одним із шляхів вирішення даної проблеми є розвиток фермерських господарств, в тому числі сімейного типу, на основі господарств населення. Досягнення поставленої мети, на наш погляд, можливе при формуванні в активного сільського населення економічного інтересу працювати у молочному бізнесі. Повинно бути чітке розуміння теоретичних та практичних основ ведення молочного скотарства, обсягу необхідних матеріально-технічних та фінансових ресурсів для одержання економічного ефекту, сума якого стимулюватиме працю селян та сприятиме розвитку їх фермерського бізнесу у довгостроковій перспективі на умовах розширеного відтворення.

Економічний інтерес формується на основі ряду абсолютних та відносних економічних показників. Одним із таких показників, які широко поширені у бізнес-плануванні, є чистий грошовий потік (ЧГП). На відміну від прибутку, який не в повній мірі відображає основні результати господарської діяльності господарюючих суб'єктів, чистий грошовий потік надає більш вичерпне розуміння економічного ефекту та враховує усі грошові потоки скориговані на суму витратної та податкової складової за винятком амортизаційних витрат. А для сімейної ферми з виробництва молока до значення чистого грошового потоку додатково включатиметься заробітна плата членів фермерського господарства та державні дотації на утримання ВРX за їх наявності.

На наш погляд, обгрунтована сума чистого грошового потоку, у розрахунку на одну сімейну молочну ферму за місяць, повинна становити не менше 1200 Євро. Значення даної суми обумовлене низкою об'єктивних причин. Зокрема, однією 3 найбільш вагомих - період окупності, оптимальне значення якого повинно становити для малого бізнесу не більше 6 років, оскільки довший термін для сімейних ферм інвестиційно не привабливий.

Наступним об'єктивним критерієм визначеного розміру чистого грошового потоку є сприяння розширеному відтворенню майбутньої сімейної ферми. Саме 1200 Євро в місяць надає можливість у подальшому заощаджувати та через відносно короткий період часу (1-2 роки) реінвестувати у розвиток господарства. Якщо припустити, що сімейна ферма складається з 2 членів сім'ї, відповідно дохід у розрахунку на одну особу становитиме 600 Свро, а це у двічі більше за середню заробітну плату в Україні за 2018 р., та приблизно дорівнює середньомісячному чистому заробітку українських робітників у Польщі, що з врахуванням особливостей ведення молочного бізнесу, сприятиме формуванню необхідного економічного інтересу у сільського працездатного населення, в тому числі молоді. Саме на підтримці молодих активних жителів сільських територій, на наш погляд, необхідно акцентувати пріоритети, при формуванні довгострокових цілей щодо розвитку молочного скотарства України. Адже однією з причин скорочення поголів'я корів у господарствах населення $€$ неспроможність людей, зазвичай старшого віку, через фізичний стан здоров'я займатися молочним скотарством, тому необхідно стимулювати поступову зміну поколінь, а забезпечення чистого грошового потоку у сумі 1200 Свро/міс стане одним з чинників, які сприятимуть такому переходу. Без формування належних стимулів, зокрема економічних, складно досягнути майбутнього розвитку сімейного фермерства у молочному скотарстві.

3 метою розуміння економічної складової організації виробництва молока у сімейних фермах визначено основні техніко-економічні критерії формування таких ферм за трьома варіантами. Перший варіант (Ферма I) - це ферма на 21 корову, саме така кількість корів необхідна для досягнення чистого грошового потоку у сумі 1200 Свро/міс при середній оптовій ціні реалізації молока вищого гатунку 8,6 грн, або 0,27 Євро та молочній продуктивності корів не менше 6200 кг за лактацію. Даний тип ферм успішно розвиватиметься на будь-яких сегментах ринку, де $\epsilon$ потреба в оптових поставках якісної молочної продукції.

Другий варіант (Ферма II) - це ферма на 9 корів, однак реалізація молока відбуватиметься за цінами, які наближені до роздрібних, а це 15 грн., або 0,47 Свро, що при досягненні аналогічних, як у першому варіанті, надоїв на корову дозволить, за рахунок вищої ціни продажу продукції, досягнути, як у першому варіанті ферми суми чистого грошового потоку.

Третій варіант (Ферма III) - це ферма на 9 корів, створена на базі існуючого господарства населення чи 
особистого селянського господарства, яке уже утримує як приклад 4 корови, однак не володіє додатковими площами для розширення поголів'я, а умови щодо продуктивності та ціни реалізації відповідають фермі другого варіанту.

Організацію другого та третього варіантів ферм, на наш погляд слід рекомендувати у сільських населених пунктах, які знаходяться поблизу обласних та районних центрів, що відносяться до тих сегментів ринку, на яких припадає значна частка споживачів готових платити роздрібну ціну за якісне молоко чи молокопродукти. Оскільки створення таких ферм у сільських територіях, які віддалені від зазначених сегментів ринку, супроводжуватиметься складнощами щодо реалізації продукції за вигідними для господарства цінами. Необхідна сума основного капіталу для організації виробництва молока вищого гатунку у сімейних фермах за основними позиціями показана у таблиці 1 .

\section{Таблиця 1}

Прогнозована сума основного капіталу для організації сімейних ферм з виробництва молока, Свро

\begin{tabular}{|c|c|c|c|c|c|c|}
\hline \multirow[b]{2}{*}{ Стаття капіталовкладень } & \multicolumn{2}{|c|}{ Ферма I * } & \multicolumn{2}{|c|}{ Ферма II** } & \multicolumn{2}{|c|}{ Ферма III*** } \\
\hline & $\begin{array}{l}\text { БДП } \\
* * * *\end{array}$ & $\begin{array}{c}\text { ЗДП } \\
* * * * *\end{array}$ & БДП & ЗДП & БДП & ЗДП \\
\hline Господарське приміщення для утримання тварин & 9968 & 5981 & 4272 & 2563 & 2373 & 1424 \\
\hline Міксер розкидач корму & 4747 & 2848 & 0 & 0 & 0 & 0 \\
\hline Змішувач корму & 0 & 0 & 506 & 304 & 506 & 304 \\
\hline Створення культурних пасовищ 0,5 га на корову із шлейфом & 1528 & 1528 & 655 & 655 & 655 & 655 \\
\hline Нетелі чорнорябої породи & 21980 & 6031 & 9420 & 2585 & 5233 & 1436 \\
\hline Поїлки автоматичні & 424 & 254 & 182 & 109 & 182 & 109 \\
\hline Годівниці & 665 & 399 & 285 & 171 & 285 & 171 \\
\hline Комунікації & 1108 & 1108 & 1108 & 1108 & 0 & 0 \\
\hline Доїльні апарати & 831 & 498 & 356 & 214 & 356 & 214 \\
\hline Гноєтранспортер & 2824 & 1695 & 1210 & 726 & 1210 & 726 \\
\hline Гноєсховище плівкове & 665 & 665 & 285 & 285 & 285 & 285 \\
\hline Танк для охолодження молока (б/у) & 1994 & 1196 & 854 & 513 & 854 & 513 \\
\hline Трактор DONGFENG, причепні (б/y) & 10000 & 6000 & 10000 & 6000 & 10000 & 6000 \\
\hline Зернодробарка & 100 & 60 & 100 & 60 & 100 & 60 \\
\hline Інше обладнання & 375 & 225 & 375 & 225 & 375 & 225 \\
\hline Разом & 57208 & 28488 & 29608 & 15517 & 22039 & 11897 \\
\hline
\end{tabular}

Джерело: власні дослідження

* Ферма I - Ферма 21 корова, оптова ціна молока 8,6 грн./0,27 Євро

** Ферма II - Ферма 9 корів, ціна молока наближена до роздрібної 15 грн./0,47 Євро

*** Ферма III - Ферма 9 корів на базі ОСГ 4 корови, ціна молока наближена до роздрібної 15 грн./0,47 Євро

**** Без державної підтримки (БДП)

***** 3 врахуванням державної підтримки (ЗДП)

Успішне функціонування ферм другого та третього типу можливе у віддалених, від описаних сегментів ринку, селах лише за умови низького рівня конкуренції на місцевому ринку, що сприятиме продажу продукції за відносно високими цінами, які наближені до роздрібних. За результатами дослідження встановлено, що для організації сімейної ферми на 21 корову (I) за “нульовим варіантом", необхідно 57,2 тис. Євро основного капіталу, або близько 28,5 тис. Свро з врахуванням державних програм підтримки, а саме компенсації 40\% вартості будівництва господарських приміщень, купівлі обладнання, технічних засобів та компенсація до 24 тис. грн./голову за купівлю нетелей. Для організації ферми на 9 корів (II) за “нульовим варіантом" необхідно до 30 тис. Євро основного капіталу, або близько 15,5 тис. 3 врахуванням державних програм підтримки розвитку молочного скотарства. Найменш капіталомістким варіантом є створення сімейної ферми (III) з виробництва молока на базі уже існуючого ОСГ, чи господарства населення, яке утримує для прикладу 4 корови, володіє необхідним господарським приміщенням 3 наявними комунікаціями та потребує додаткової купівлі 5 нетелей, з метою розширення ферми до 9 корів та переходу на вищий рівень товарності.

Слід зазначити, що сума основних капіталовкладень суттєво залежить від уже наявного матеріальнотехнічного забезпечення господарства. Для третього варіанту сімейної ферми необхідно додатково залучити 22 тис. Євро без державної підтримки, або 12 тис. Євро при використанні державних програм розвитку. Визначена сума буде у двічі меншою, якщо потенційне господарство, на основі якого планується створення ферми, володітиме трактором та господарськими приміщеннями достатньої площі щоб утримувати 9 корів 3 телятами на відгодівлі.

Крім залучення основного капіталу для організації сімейної ферми з безперебійним виробництвом продукції, необхідно забезпечити кормову базу, паливномастильні матеріали, підстилковий матеріал, ветеринарні засоби, кошти на рахунках та інші оборотні засоби (табл. 2).

Основна частка оборотного капіталу припадає на вартість кормів. Загалом понад 1000 Євро на корову та додатково до 250 Євро на відгодівлю молодняка ВРX включно з резервом. На наш погляд, економічно доцільніше для сімейних ферм, які відносяться до 
малих агроформувань, купувати основні кормові компоненти за ринковими цінами, а ніж заготовляти їх самостійно. Проблема полягає у тому, що досягнення високих показників продуктивності корів не можливе без використання у годівлі збалансованих раціонів. Оптимальний раціон годівлі для корів включає 8-10 і більше кормових компонентів, вирощування яких у малих тваринницьких фермах економічно не обгрун- товано, оскільки потребує залучення дорогої техніки, обладнання, додаткових приміщень для зберігання урожаю, що є абсолютно не виправдано на малих площах, адже повна собівартість вирощених кормів часто перевищує, або близька до значення ринкової ціни, за таких умов окупність капіталовкладень перевищу 10 років, що є інвестиційно не привабливо для більшості інвесторів.

\section{Таблиця 2}

Прогнозована сума оборотного капіталу на рік для організації сімейних ферм з виробництва молока, Свро

\begin{tabular}{lccc}
\hline \multicolumn{1}{c}{ Стаття оборотного капіталу } & Ферма I & Ферма II & Ферма III \\
\hline Пальне та паливно-мастильні матеріали & 824 & 530 & 530 \\
Корми & 27323 & 11710 & 11710 \\
Підстилка & 243 & 104 & 104 \\
Електроенергія & 555 & 357 & 357 \\
Вода & 267 & 114 & 114 \\
Ветеринарні препарати & 196 & 84 & 84 \\
Кошти на рахунках & 332 & 142 & 142 \\
Швидкозношуваний інвентар & 100 & 43 & 43 \\
Матеріали та засоби для обробки та дезінфекції приміщення & 133 & 57 & 57 \\
Інший оборотний капітал & 166 & 71 & 71 \\
Разом & 30139 & 13212 & 13212 \\
\hline
\end{tabular}

Джерело: власні дослідження

Вирощування основних кормових компонентів економічно доцільне у великих тваринницьких фермах та зазвичай себе не виправдовує у малих господарюючих суб'єктах, основною конкурентною перевагою яких повинна бути спеціалізація, саме завдяки їй сімейні ферми, на наш погляд, здатні досягнути достатньо високих показників економічної ефективності. Необхідна сума оборотного капіталу на рік для орга- нізації ферми на 21 корову становитиме понад 30 тис. Свро та близько 13,5 тис. Свро для ферми на 9 корів. Потреба в оборотних засобах розрахована на рік функціонування ферми, відповідно іiі можливо знизити, якщо закупівлю необхідної сировини та матеріалів здійснювати раз на пів року, або в квартал, однак слід враховувати сезонне зростання цін на корми.

\section{Таблиця 3}

Прогнозування необхідного авансованого капіталу для організації сімейних ферм з виробництва молока

\begin{tabular}{ccccccc}
\hline \multirow{2}{*}{$\begin{array}{c}\text { Разом авансованого } \\
\text { капіталу }\end{array}$} & \multicolumn{2}{c}{ Ферма I } & \multicolumn{2}{c}{ Ферма II } & \multicolumn{2}{c}{ Ферма III } \\
\cline { 2 - 7 } & БДП & ЗДП & БДП & БДП & ЗДП & БДП \\
\cline { 2 - 7 } & 87347 & 58627 & 42820 & 28729 & 35251 & 25109 \\
\hline
\end{tabular}

Джерело: власні дослідження

Сукупна вартість основного та оборотного капіталу (табл. 3) для сімейних ферми на 21 та 9 корів за “нульовим варіантом" становить 87 та 43 тис. Євро, або 59 та 29 тис. Євро з врахуванням програм державної підтримки у молочному скотарстві. Найменша сума авансованого капіталу необхідна для створення сімейної ферми на базі уже існуючого господарства населення, яке уже утримує для прикладу 4 корів 25-35,3 тис. Євро в залежності від рівня капіталозабезпечення та наявної державної підтримки.

Кормова база складається із закуплених кормів та зеленої маси культурних пасовищ. У зимовостійловий період ВРX годуватимуть закупленими кормами (100\%), а в пасовищний період 50\% раціону прогнозовано забезпечуватиметься кормовою базою створених культурних пасовищ. Раціон годівлі не є еталонним, а лише один із багатьох прикладів, який повинен виходити 3 доступності кормових компонентів у районі створення ферми. Доцільність використання закуплених кормів для малих ферм описувалася вище.

Сімейна ферма на 21 корову, при продуктивності не менше 6200 кг молока на одну корову за рік виробить понад 120 тис. кг товарного молока 3 прогнозованою жирністю не менше $3,8 \%$, що у перерахунку на базову жирність становитиме майже 136 тис. кг. Додатково ферма відгодовуватиме до 1 річного віку молодняк ВРX на м'ясо в обсязі до 7 т в живій вазі. Виробництво товарного молока за рік фермою на 9 корів прогнозовано становитиме до 52 тис. кг з врахуванням випоювання телят 400 кг/голову, а також власного споживання 600 кг/рік. Рівень товарності за таких умов становитиме 93-94\%. 
Таблиця 4

Середньорічні витрати на корми для 1 корови без врахування кормової бази культурних пасовищ

\begin{tabular}{lcccccc}
\hline \multicolumn{1}{c}{ Компонент корму } & $\begin{array}{c}\text { Ціна за 1 } \\
\text { кг, Свро }\end{array}$ & $\begin{array}{c}\text { Струк- } \\
\text { тура, \% }\end{array}$ & $\begin{array}{c}\text { Обсяг корму } \\
\text { на 1 голову } \\
\text { за 1 день, г }\end{array}$ & $\begin{array}{c}\text { Вартість добо- } \\
\text { вого раціону на } \\
\text { 1 голову, Євро }\end{array}$ & $\begin{array}{c}\text { Потреба в } \\
\text { кормах за рік } \\
\text { на 1 голову, ц }\end{array}$ & $\begin{array}{c}\text { Вартість } \\
\text { карупленого Свро }\end{array}$ \\
\hline Пшениця & 0,14 & 6 & 2700 & 0,38 & 9,9 & 137 \\
Кукурудза & 0,13 & 6 & 2700 & 0,35 & 9,9 & 128 \\
Ячмінь & 0,14 & 6 & 2700 & 0,38 & 9,9 & 140 \\
Макуха соняшникова & 0,19 & 3 & 1350 & 0,26 & 4,9 & 94 \\
Силос кукурудзяний & 0,03 & 25 & 11250 & 0,32 & 24,8 & 70 \\
Сінаж & 0,03 & 24 & 10800 & 0,38 & 23,8 & 83 \\
Сіно люцерни & 0,06 & 23 & 10350 & 0,66 & 22,8 & 144 \\
Мінеральні корми & 0,16 & 1 & 450 & 0,07 & 1,6 & 26 \\
Пивна дробина & 0,13 & 5 & 2250 & 0,28 & 5,0 & 63 \\
Премікс для корів & 0,95 & 1 & 450 & 0,43 & 1,6 & 156 \\
Разом для корів & $\mathrm{X}$ & 100 & 45000 & 3,50 & 114,0 & 1041 \\
На відгодівлю 1 голови & $\mathrm{X}$ & $\mathrm{X}$ & 11250 & 0,88 & 28,5 & 260 \\
молодняка ВРХ (+25\%) & $\mathrm{X}$ & $\mathrm{X}$ & 56250 & 4,38 & 142,5 & 1301 \\
Разом витрат корму & & & &
\end{tabular}

Джерело: власні дослідження

Основною статтею витрат традиційно у тваринництві, в тому числі молочному скотарстві, є вартість кормів. Також слід зазначити, що витрати на оплату праці членів сімейної ферми є умовною статтею, оскільки кошти залишатимуться у сім’і, відповідно визначена сума відноситиметься до чистого грошового потоку. 3 метою заощадження на сплаті ССВ розра- хунок заробітної плати для членів сімейної ферми проводився за мінімально встановленим рівнем 4173 грн. станом на 1 січня 2019 р., що у перерахунку на Євро - 3169 за рік. Собівартість виробництва 1 кг молока у сімейних фермах прогнозовано становитиме від 0,21 - 0,26 Євро, в залежності від зазначених у таблиці 5 варіантів масштабу виробництва.

Таблиця 5

Прогнозування обсягів виробництва та реалізації продукції скотарства у сімейних фермах

\begin{tabular}{lccc}
\hline \multicolumn{1}{c}{ Показник } & Ферма I & Ферма II & Ферма III \\
\hline Кількість корів, голів & 21 & 9 & 9 \\
Надій молока на корову за рік, кг & 6200 & 6200 & 6200 \\
Обсяг одержаного молока за рік, кг & 130200 & 55800 & 55800 \\
Діловий вихід телят, \% & 95 & 95 & 95 \\
Одержано телят, голів & 20 & 9 & 9 \\
Витрачено молока на випоювання телят (400 кг/голову), кг & 7980 & 3420 & 3420 \\
Товарність молока, \% & 94 & 93 & 93 \\
Обсяг продажу молока, кг & 121620 & 51780 & 51780 \\
Середня жирність молока, \% & 3,8 & 3,8 & 3,8 \\
Обсяг продажу молока у базовій жирності (3,4\%), кг & 135928 & $51780^{*}$ & $51780^{*}$ \\
Вага 1 голови молодняка ВРХ при реалізації на м'ясо, кг & 350 & 350 & 350 \\
Вага реалізованого на забій молодняка ВРХ (14-16 міс.) в середньому, кг & 6983 & 2993 & 2993 \\
\hline
\end{tabular}

*При роздрібному продажу молока перерахунок у базову жирність не враховувався

Джерело: власні дослідження

Амортизація, в умовах сімейної ферми не розраховувалася, оскільки відноситься до чистого грошового потоку, тобто залишається у розпорядженні господарства. Доцільність та необхідність розрахунку амортизації існує при загальній системі оподаткування, де сплачують податок на прибуток, відповідно з метою заниження бази оподаткування, застосовують різні методики прискореного нарахування зносу основних фондів, для зниження суми податку на прибуток, за рахунок завищення виробничих витрат. Для сімейних ферм та інших господарюючих суб'єктів, які знаходяться на спрощеній системі оподаткування із мінімальними вимогами до звітності, розрахунок амортизації обгрунтований лише для економічної обізнаності власників про “реальні” витрати своїх господарств.
Важливою умовою швидкої окупності сімейних ферм, як показали розрахунки у табл. 7, є наявність державної підтримки та величина ціни продажу молока. Так, ферма на 21 корову, яка реалізує молоко за оптовими цінами - 0,27 Євро/кг, одержить чистий грошовий потік (ЧГП) на суму 14,5 тис. Свро за рік.

Окупність прогнозовано становитиме 6,5 роки 3 часу реалізації проекту (6 років з часу реалізації молока), або близько 4 років за наявності державної підтримки, яка суттєво впливає на суму ЧГП, оскільки дозволяє одержувати виплати на корову та телят, які для ферми на 21 корову за рік становитимуть 2579 Євро, а це дозволить підвищити суму ЧГП на сімейну ферму за місяць до 1420 Свро. 


\section{Таблиця 6}

Прогноз основних статей витрат на виробництво молока у сімейних фермах

\begin{tabular}{lccc}
\hline \multicolumn{1}{c}{ Стаття витрат } & Ферма I & Ферма II & Ферма III \\
\hline Пальне та паливно-мастильні матеріали & 824 & 530 & 530 \\
Корми & 27323 & 11710 & 11710 \\
Підстилка & 243 & 104 & 104 \\
Електроенергія & 555 & 357 & 357 \\
Вода & 267 & 114 & 114 \\
Ветеринарні препарати & 196 & 84 & 84 \\
Швидкозношуваний інвентар & 100 & 43 & 43 \\
Матеріали та засоби для обробки та дезінфекції приміщення & 133 & 57 & 57 \\
Інший виробничі витрати & 166 & 71 & 71 \\
Заробітна плата членів ферми & 3169 & 3169 & 3169 \\
ССВ (сплата 10\% у 1-ший рік) & 70 & 70 & 70 \\
Амортизація (для сімейних ферм не враховано) & 0 & 0 & 0 \\
Разом виробничих витрат & 33046 & 16309 & 16309 \\
Витрати на збут продукції & 0 & 162 & 162 \\
Оренда землі (пасовища) & 332 & 142 & 142 \\
Разом інших операційних витрат & 332 & 304 & 304 \\
Всього операційних витрат & 33378 & 16613 & 16613 \\
на 1 кг молока з вирахуванням витрат на вирощування ВРХ & 0,21 & 0,26 & 0,26 \\
\hline
\end{tabular}

Джерело: власні дослідження

\section{Таблиця 7}

Економічна ефективність та інвестиційна привабливість виробництва молока у сімейних фермах, Свро

\begin{tabular}{|c|c|c|c|c|c|c|}
\hline \multirow{2}{*}{ Показник } & \multicolumn{2}{|c|}{ Ферма I } & \multicolumn{2}{|c|}{ Ферма II } & \multicolumn{2}{|c|}{ Ферма III } \\
\hline & БДП & ЗДП & БДП & ЗДП & БДП & ЗДП \\
\hline Ціна 1 кг молока, без ПДВ & 0,27 & & 0,47 & & 0,47 & \\
\hline Ціна 1 кг живої маси ВРХ без ПДВ & 1,17 & & 1,17 & & 1,17 & \\
\hline Обсяг продажу молока, кг & 135928 & & 51780 & & 51780 & \\
\hline Виручка від реалізації молока & 36993 & & 24579 & & 24579 & \\
\hline Обсяг продажу ВРХ, кг & 6983 & & 2993 & & 2993 & \\
\hline Виручка від реалізації ВРХ на м’ясо & 8176 & & 3504 & & 3504 & \\
\hline Виручка від реалізації продукції скотарства & 45169 & & 28083 & & 28083 & \\
\hline Виробничі витрати & 33046 & & 16309 & & 16309 & \\
\hline Інші операційні витрати & 332 & & 304 & & 304 & \\
\hline Всього витрат & 33378 & & 16613 & & 16613 & \\
\hline Єдиний податок (2 група 20\% від мін. зарплати) & 317 & & 317 & & 317 & \\
\hline Прибуток від реалізації продукції скотарства & 11474 & & 11153 & & 11153 & \\
\hline $\begin{array}{l}\text { Чистий грошовий потік (ЧГП) з врахуванням } \\
\text { встановленої заробітної плати членів сімейної ферми }\end{array}$ & 14643 & 17218 & 14406 & 15426 & 14406 & 15426 \\
\hline у розрахунку на місяць & 1220 & 1435 & 1200 & 1285 & 1200 & 1285 \\
\hline Співвідношення ЧГП до витрат, \% & 43,9 & 51,6 & 86,2 & 92,9 & 86,2 & 92,9 \\
\hline Співвідношення ЧГП до виручки від реалізації, \% & 32,4 & 38 & 51,0 & 55 & 51,0 & 55 \\
\hline Співвідношення ЧГП до авансованого капіталу, \% & 16,8 & 29,4 & 30,3 & 49,1 & 41 & 62 \\
\hline Період окупності, років & 6,47 & 4,00 & 3,80 & 2,64 & 3,1 & 2,2 \\
\hline Коефіцієнт податкового навантаження & \multicolumn{2}{|c|}{$0,031-0,075$} & \multicolumn{2}{|c|}{$0,052-0,09$} & \multicolumn{2}{|c|}{$0,052-0,09$} \\
\hline
\end{tabular}

Джерело: власні дослідження

Розвиток сімейних ферм на 9 корів при ціні продажу молока наближеній до роздрібної - 0,47 Євро/кг $\epsilon$ найбільш інвестиційно привабливим, враховуючи те, що період окупності капіталовкладень у них 2,53,5 роки. Даний тип ферм потенційно спроможний досягнути високих показників співвідношення ЧГП до стартового капіталу, що формує значний економічний інтерес для організації бізнесу з виробництва молока.

Найбільш економічно привабливим, оцінюючи визначені показники економічної та інвестиційної ефективності, $є$ розвиток ферм на базі господарств населення чи ОСГ, які уже утримують певну кількість корів та володіють необхідними матеріально- технічними ресурсами. Створення таких ферм відноситься до найбільш простіших серед визначених варіантів, та характеризується швидкою окупністю, оскільки додаткова сума авансованого капіталу на їх організацію значно нижча, ніж у другому типі ферм на 9 корів.

Сприятливим чинником розвитку сімейних ферм 3 виробництва молока $є$ відносно низький коефіцієнт податкового навантаження, який становить від $0,031-$ 0,075 , а це означає, що 3 кожного 1 Євро вартості реалізованої продукції, сума податкових платежів становитиме 0,03-0,075 Євро. Найнижче значення коефіцієнта становитиме у перший рік роботи ферми, враховуючи наявність державної компенсації сплати 
90\% ЄСВ. Податковий тиск поступово збільшуватиметься із зниженням компенсацій ССВ на $10 \%$ щорічно. Для ферм на 9 корів, коефіцієнт податкового навантаження $\epsilon$ вищим в середньому на 1,5-2 процентних пункти, через більшу частку ССВ у розрахунку на одиницю вартості продукції. Спрощена система оподаткування, фермам 3 виробництва молока, надає можливість сплачувати загалом у двічі меншу суму податків, у розрахунку на одиницю вартості реалізованої продукції, порівняно з сільськогосподарськими підприємствами юридичними особами, які знаходяться на загальній системі оподаткування.

На рівень економічного ефекту сімейної ферми впливає значна кількість як внутрішніх, так і зовнішніх чинників. Найвища залежність спостерігається між ЧГП та ціною реалізації молока, а також рівнем продуктивності корів. Однак, на думку чеських науковців, технологічна ефективність не $€$ найважливішим фактором, що визначає прибутковість. Зміна ціни впливає на зміну прибутковості значно більше (Zakova Kroupova, 2016). Ціна є також мотиваційним чинником у молочному скотарстві для фермерів (Gorbanyuk, 2018). Фермери, які виробляють молоко повинні сприяти підвищенню ринкових цін на продукцію, наприклад, шляхом створення маркетингових асоціацій (Michaličková et al., 2014).

Відповідно ферма повинна використовувати усі можливості продажу навіть незначного обсягу виробленої продукції за цінами, які наближені до роздрібних. Якщо ферма на 21 корову реалізуватиме лише
10\% молока за ціною 15 грн (0,47 Свро)/кг, середня ціна продажу зросте від 8,6 до 9,15 грн., або на 7,6 процентних пунктів, що дозволить підвищити співвідношення ЧГП до авансованого капіталу на 3 п.П., а це додатково 2,6 тис. Свро на рік, що є досить суттєво для такої ферми. Вплив продуктивності корів на ЧГП становитиме в середньому, для ферми на 21 корову, у 30 Євро в місяць на кожен 1\% зміни надоїв від фактично визначених 6200 кг/рік. Це означає, що зростання надоїв на 10\% до 6820 кг/рік забезпечить підвищення середньомісячного ЧГП на 300 Свро, і навпаки, при їх зниженні, за умови рівності усіх інших чинників. Саме тому врахування описаних чинників сприятиме зростанню економічної ефективності функціонування сімейних ферм в Україні, а також дозволить підвищити їх конкурентоспроможність на ринку. Варто зазначити, що сума ЧГП об'єктивно залежить від масштабів ферми, які визначаються чисельністю корів (табл. 8).

Так, ферма на три корови при ціні реалізації молока 0,27 євро/кг одержуватиме в середньому не більше 100 євро ЧГП на місяць. Зростання чисельності корів до 10 голів дозволить підвищити рівень чистої дохідності до 500-600 євро на місяць. Для забезпечення обгрунтованого рівня чистого грошового потоку у сумі 1200 євро на місяць, який стимулюватиме економічний інтерес до даного виду агробізнесу, необхідно утримувати, за нашими розрахунками, не менше 20 корів.

\section{Таблиця 8}

Варіанти рівня чистого грошового потоку на ферму за місяць в залежності від зміни чисельності корів при фіксованій ціні продажу 1 кг молока $(0,27$ Свро)

\begin{tabular}{lcccccccccc}
\hline \multicolumn{1}{c}{ Показник } & \multicolumn{10}{c}{ Baріанти } \\
\cline { 2 - 10 } & 1 & 2 & 3 & 4 & 5 & 6 & 7 & 8 & 9 \\
\hline $\begin{array}{l}\text { Сума чистого грошового потоку на } \\
\text { ферму за місяць, євро }\end{array}$ & 80 & 150 & 200 & 290 & 425 & 560 & 700 & 910 & 1213 \\
Чисельність корів, голів & 3 & 4 & 5 & 6 & 8 & 10 & 12 & 15 & 21 \\
\hline
\end{tabular}

Джерело: власні дослідження

Відповідно збільшення чисельності корів, а відтак масштабів виробництва, дасть можливість сімейним фермам одержувати вищий рівень економічного ефекту. Розрахунки щодо моделювання впливу рівня ціни продажу молока на чисельність корів, яка дозволить одержати визначений рівень середньомісячного чистого грошового потоку на ферму наведено у таблиці 9.

\section{Таблиця 9}

Варіанти необхідного поголів'я корів та рівня ціни продажу молока для забезпечення чистого грошового потоку на ферму 1200 Свро/міс

\begin{tabular}{lccccccccc}
\hline \multicolumn{1}{c}{ Показник } & \multicolumn{10}{c}{ Варіанти } \\
\cline { 2 - 10 } & 1 & 2 & 3 & 4 & 5 & 6 & 7 & 8 & 9 \\
\hline Ціна 1 кг молока, грн. & 32 & 25 & 21 & 18 & 15 & 13 & 11,5 & 10 & 8,5 \\
Ціна 1 кг молока, євро & 1,01 & 0,79 & 0,66 & 0,57 & 0,47 & 0,41 & 0,36 & 0,32 & 0,27 \\
Чисельність корів, голів & 3 & 4 & 5 & 6 & 8 & 10 & 12 & 15 & 21 \\
\hline
\end{tabular}

Джерело: власні дослідження

Слід зазначити, що досягнути ЧГП у сумі 1200 євро на ферму у розрахунку на місяць можливо з меншим поголів'ям корів та обсягами реалізації, однак ціна реалізації молока повинна бути роздрібною. Як приклад, ферма на 6 корів досягне зазначеного рівня чистого грошового потоку при ціні реалізації молока не нижче 0,57 євро/кг. Враховуючи результати проведених досліджень, малим фермам з поголів'ям п'ять i 
менше корів буде проблематично досягнути обгрунтованого економічного ефекту, який здатний забезпечити достатньо високий інвестиційний інтерес для розвитку молочного скотарства.

Разом із тим слід зазначити, що кількість поголів'я корів не є визначальним щодо величини валових надоїв молока, і відповідно, продуктивності молочного стада. За результатами досліджень вчених, підприємства, які утримують незначну кількість високопродуктивних корів, мають значно вищі показники ефективності виробництва, ніж у висококонцентрованих господарствах (Ivanova, 2017). Подібної позиції дотримуються науковці у Швейцарії на думку яких, не було встановлено чіткої залежності між масштабами виробництва та рівнем прибутковості у молочних фермах країни (Mamardashvili \& Schmid, 2013).

Отже, розвиток молочного скотарства у сімейних фермах, на наш погляд, повинен відбуватися з врахуванням визначених та описаних економічних критеріїв, відповідно до яких пропонується створення ферм 3 поголів'ям не менше 20 корів при оптовій ціні реалізації молока, а також ферм 3 поголів'ям не менше 9 корів, в тому числі створених на базі уже існуючих ОСГ при умові організації продажу виробленої продукції за цінами, які наближені до роздрібних, з метою досягнення достатньої суми середньомісячного чистого грошового потоку, що сприятиме формуванню економічного та інвестиційного інтересу, серед працездатних жителів сільських територій, виробляти молоко.

У зв’язку зі змінами в управлінні сільськими територіями (децентралізація) актуальним є питання подальшого розвитку особистих селянських господарств на основі єдності економічних, соціальних і екологічних інтересів та активізації підприємницької діяльності в частині зростання доходів, зайнятості й соціального захисту шляхом розвитку сімейних ферм (Malik et al., 2016).

Основним шляхом підвищення рівня виробництва продукції скотарства повинно стати поліпшення економічних умов господарювання в галузі, збереження i примноження теперішнього поголів'я великої рогатої худоби, зокрема корів, та нарощування продуктивності тварин, зокрема за рахунок нових продуктивніших порід тварин (Berezivskiy et al., 2018).

\section{Висновки}

Відповідно до результатів проведених досліджень обгрунтовано, що розвиток виробництва молока у фермерських господарствах, в тому числі сімейного типу, можливий при досягнені певних економічних критеріїв, зокрема граничної суми економічного ефекту, ціни реалізації та чисельності поголів'я корів. Визначено, що чистий грошовий потік у розрахунку на одну ферму за місяць повинен становити не менше 1200 євро для забезпечення відносно швидкого періоду окупності інвестицій, сприяння розвитку таких господарств на умовах розширеного відтворення, а також формування економічного інтересу серед жителів сільських територій займатися виробництвом молока, що можливо досягнути при поголів’і 9-20 корів на ферму в залежності від рівня ціни реалізації продукції. Для створення ферм 3 виробництва молока запропонованих типів, необхідно залучити від 25 до 60 тис. євро інвестицій з врахуванням державної програми компенсації частини вартості основних засобів, період окупності яких, в залежності від ціни реалізації, масштабів виробництва та наявності державної підтримки прогнозовано становитиме 3-6 роки. Найбільш економічно привабливий, оцінюючи визначені показники економічної та інвестиційної ефективності, $\epsilon$ розвиток ферм на базі господарств населення чи ОСГ, які уже утримують певну кількість корів та володіють необхідними матеріально-технічними ресурсами. Створення ферм, зокрема сімейного типу на базі господарств населення, дозволить задіяти додаткові резерви розвитку молочного скотарства України та підвищити загалом економічний потенціал галузі.

Перспективи подальших досліджень. Подальші дослідження проводитимуться щодо визначення вагомості впливу основних технологічних та економічних чинників на ефективність функціонування фермерських господарств, зокрема сімейного типу для виявлення та обгрунтування основних резервів підвищення їх прибутковості та конкурентоспроможносTi.

\section{References}

Berezivskiy, Z., Berezivska, O., \& Berezivskiy, Y. (2018). Ekonomichnyi stan vyrobnytstva produktsii skotarstva u silskohospodarskykh pidpryiemstvakh Lvivskoi oblasti. Naukovyi visnyk LNU veterynarnoi medytsyny ta biotekhnolohii. Seriia "Ekonomichni nauky", 20(91), 84-87. doi: 10.32718/nvlvet9117 (in Ukrainian).

Gorbanyuk, V. (2018). Obsluhovuiucha neprybutkova kooperatsiia i optymalne tsinoutvorennia - priorytet ahrarnoi reformy $\mathrm{v}$ molochnomu tvarynnytstvi silskykh domohospodarstv Ukrainy. Naukovyi visnyk LNU veterynarnoi medytsyny ta biotekhnolohii. Seriia "Ekonomichni nauky", 20(91), 66-73. doi: 10.32718/nvlvet9114 (in Ukrainian).

Ivanova, L.S. (2017). Molochne skotarstvo: suchasnyi stan ta problemy vyrishennia. Ahrosvit, 22, 23-27. http://www.agrosvit.info/pdf/22_2017/5.pdf (in Ukrainian).

Malik, M.Y., \& Shpykuliak, O.H. (2018). Tendentsii i perspektyvy rozvytku osobystykh selianskykh hospodarstv. Ekonomika APK, 1, 11-19 (in Ukrainian).

Malik, M.Y., Lupenko, Yu.O., \& Zaiats, V.M. (2016). Rozvytok pidpryiemnytstva i kooperatsii: instytutsionalnyi aspekt. K.: NNTs "IAE" (in Ukrainian).

Mamardashvili, P., \& Schmid, D. (2013). Performance of Swiss dairy farms under provision of public goods. Agric. Econ. - Czech, 59, 300-314. doi: 10.17221/148/2012-AGRICECON (in Czech).

Maslak, O. (2017). Ukrainskyi rynok yalovychyny: problemy ta perspektyvy. Propozytsiia, 2, 9-12 (in Ukrainian). 
Michaličková, M., Krupová, Z., Polák, P., Hetényi, L., \& Krupa, E. (2014). Development of competitiveness and its determinants in Slovak dairy farms. Agric. Econ. - Czech, 60, 82-88. doi: 10.17221/76/2013AGRICECON (in Czech).

Nitsenko, V.S. (2013). Rozvytok molochnoho skotarstva $\mathrm{v}$ umovakh intehratsii. Naukovi pratsi PDAA, 1(6),199-208. https:/www.pdaa.edu.ua/sites/default/ files/nppdaa/6.1/199.pdf (in Ukrainian).

Semenda, D.K., Semenda, O.Vs., \& Semenda, O.V. (2018). Derzhavna pidtrymka u vidnovleni haluzi molochnoho skotarstva Molodyi vchenyi, 3(55), 376-380. http://molodyvcheny.in.ua/files/journal/2018/3/85.pdf (in Ukrainian).

Špička, J. \& Smutka, L. (2014). The Technical Efficiency of Specialised Milk Farms: A Regional View. The Scientific World Journal, 2014, 1-13. doi: 10.1155/2014/985149 (in Czech).

Zakova Kroupova, Z. (2016). Profitability development of Czech dairy farms. Agric. Econ. - Czech, 62, 269279. doi: 10.17221/131/2015-AGRICECON (in Czech). 